\title{
Worsening of Serum Lipid Profile after Direct Acting Antiviral Treatment
}

\author{
Stefano Gitto, ${ }^{*} \bullet$ Arrigo F. G. Cicero, ${ }^{*}, \bullet$ Elisabetta Loggi, ${ }^{*}$ Marina Giovannini, ${ }^{* \star}$ Fabio Conti, ${ }^{\star}$ Elena Grandini, ${ }^{*}$ Valeria Guarneri, ${ }^{*}$ \\ Alessandra Scuteri, ${ }^{,}$Giovanni Vitale, ${ }^{\star}$ Carmela Cursaro, ${ }^{\star}$ Claudio Borghi, ${ }^{*}$ Pietro Andreone ${ }^{\star}$
}

* Hepatology Unit. Department of Medical and Surgical Sciences, University of Bologna and Sant'Orsola-Malpighi Hospital, Bologna, Italy. ** Internal Medicine Unit. Department of Medical and Surgical Sciences, University of Bologna and Sant'Orsola-Malpighi Hospital, Bologna, Italy.

- These authors equally contributed to the manuscript.

\begin{abstract}
Introduction. Host lipid metabolism influences viral replication and lifecycle of hepatitis $\mathrm{C}$ virus. Our aim was to evaluate changes in glucose and lipid metabolism of patients with chronic hepatitis $\mathrm{C}$ after therapy with direct acting antivirals (DAA). Material and methods. We considered patients consecutively treated between January and November 2015 recording clinical data at baseline and week 24 of follow-up. Frozen serum samples were used for apolipoprotein A1 (apoA1), apolipoprotein B (apoB) and lipoprotein (a) $[\mathrm{Lp}(\mathrm{a})]$. Wilcoxon test was utilized to estimate trends and Logistic Regression for predictors of lipid changes. Results. We enrolled 100 patients, mostly cirrhotic $(81 \%)$ and with genotype $1 \mathrm{~b}(59 \%)$. Ninety-three patients achieved sustained virological response (SVR), while 7 relapsed. Homeostasis model assessment of insulin resistance declined (from 3 to 2.7, $p<0.001$ ); non-high density lipoprotein (HDL) cholesterol increased from $102 \pm 29$ to $116 \pm 35(\mathrm{p}<0.001)$, and $\mathrm{Lp}(\mathrm{a})$ from $5.6 \pm 6.5$ to $9.8 \pm 11.5 \mathrm{mg} / \mathrm{dL}(\mathrm{p}<$ 0.001 ). Rise of low-density lipoprotein/HDL and apoB/apoA1 ratio were registered (from $1.79 \pm 1.10$ to $2.08 \pm 1.05$ and from $0.48 \pm$ 0.18 to $0.53 \pm 0.18 \mathrm{mg} / \mathrm{dL}, \mathrm{p}<0.001)$. We conducted a subanalysis on patients with relapse. In this subgroup, no change of lipid profile was recorded. At multivariate analysis emerged that the addition of ribavirin to DAA, represented an independent predictor of increased $\mathrm{Lp}(\mathrm{a})(\mathrm{OR} 3.982,95 \% \mathrm{Cl} 1.206-13.144, \mathrm{p}=0.023)$. Conclusion. DAA therapy led to reduction of insulin resistance. In contrast, pro-atherogenic lipid changes were observed in patients with SVR. Further studies will be necessary to evaluate the cardiovascular balance between amelioration of glucose metabolism and negative changes of lipid profile.
\end{abstract}

Key words. Hepatitis C virus. Chronic hepatitis C. Antiviral therapy. Lipid metabolism. Glucose metabolism.

\section{INTRODUCTION}

Host lipids show a central role in hepatitis $\mathrm{C}$ virus (HCV) cell entry, polyprotein processing, replication, assembly and release. ${ }^{1-3} \mathrm{HCV}$ binds low-density lipoprotein (LDL) and very low-density lipoprotein circulating as lipoviroparticle 4 and this association seems to be important to escape the humoral immune response. ${ }^{5}$

Chronic hepatitis $\mathrm{C}(\mathrm{CHC})$ is associated with reduced total cholesterol, LDL and apolipoprotein B (ApoB) levels $^{6}$ as well as with an increased rate of insulin resistance (IR) and type 2 diabetes mellitus. ${ }^{7}$ In the interferon (IFN) era, the alterations of glucose metabolism associated to $\mathrm{HCV}$ were reversible after viral clearance. ${ }^{8,9}$ Concerning the effect of IFN on lipids, available data are conflicting. ${ }^{10-}$ ${ }^{12}$ However, Hsu, et al. ${ }^{13}$ reported that viral eradication due to IFN may significantly decrease cardiovascular (CV) morbidity.

Data regarding effect of direct-acting antivirals (DAA) on glucose and lipid metabolism are incomplete, extrapolated from clinical trials and partially contradictory.

Meissner, et al. ${ }^{14}$ reported that HCV clearance due to sofosbuvir (SOF) and ribavirin (RBV) led to early increase of ApoB/apolipoprotein A1 (ApoA1) ratio and LDL (after 
4 weeks of antiviral therapy), but these lipid changes disappeared later during treatment.

Other authors showed that negative lipid changes might persist over time. Younossi, et al. ${ }^{15}$ analyzed CHC genotype (GT) 2 and 3 patients who received SOF and RBV. Four weeks after the end of therapy, GT3 patients showed significant increases in $\mathrm{ApoB}$, high-density lipoprotein (HDL) and LDL as well as a decrease in apolipoprotein E. Mauss, et al. ${ }^{11}$ reported a median LDL increase of $17 \mathrm{mg} / \mathrm{dL}$ at 12 weeks after the end of DAA therapy. Hashimoto, et al. ${ }^{16}$ suggested that the rapid suppression of HCV core protein by DAA might result in a decrease of lipid droplet production in HCV-infected liver cells, leading to a massive rebound of circulating LDL.

The whole analysis of lipid metabolism should include not only cholesterol and triglycerides but also other lipid patterns. ApoB/ApoA1 ratio is a better predictor of CV disease compared to LDL alone, ${ }^{17,18} \mathrm{ApoB}$ is the best direct marker of atherogenic small dense $\mathrm{LDL}^{19}$ and ApoA1 provides a good estimate of HDL. ${ }^{20}$ Lipoprotein (a) [Lp(a)] consists of a cholesterol-laden LDL-like particle bound to a plasminogen-like glycoprotein. ${ }^{21}$ Interestingly, $\mathrm{Lp}(\mathrm{a})$ is genetically determined and represents a drug-resistant independent risk factor for CV disease. ${ }^{22}$

Regarding lipoproteins, Younossi, et al. ${ }^{23}$ selected GT1 subjects with sustained virological response (SVR) after treatment with ledipasvir/SOF ( $\pm \mathrm{RBV})$. At week 4 after treatment, ApoB and LDL increased while ApoA1 and apolipoprotein E declined.

We aimed to evaluate changes of glucose and lipid metabolism due to DAA treatment in a real-life context.

\section{MATERIAL AND METHODS}

\section{Study design}

This was a cohort study on consecutively treated patients with HCV infection who received interferon-free regimens at a tertiary referral center in Emilia Romagna (Italy). Patients began antiviral therapy between January and November 2015. DAA protocol, treatment length and addition of RBV were established following the priority criteria of Italian Medicines Agency committee. ${ }^{24}$ Eligible patients were aged 18 years or older who were positive for HCV infection as established by both positive serum HCV antibody titers and serum HCV-ribonucleic acid (using real-time Polymerase Chain Reaction-based method), had evidence of liver fibrosis as assessed by biopsy or non-invasive test [Transient Elastography $\left(\right.$ FibroScan $\left.{ }^{\circledR}\right)$ ] and were followed for at least 24 weeks after therapy. Liver transplantation represented an exclusion criterion. At baseline and at the 24-week follow-up, the following data were collected: diet and exercise pattern, pharmacological therapy, body mass index, waist circumference, blood pressure, fasting laboratory tests including whole glucose and lipid profiles [glycemia, insulin, homeostatic model assessment of IR (HOMA-IR), total cholesterol, LDL, HDL, the LDL/HDL ratio, non-HDL cholesterol, triglycerides] and liver function tests (with calculation of Child-Turcotte-Pugh and Model for End-stage Liver Disease). Criteria for metabolic syndrome (MS) ${ }^{25}$ were assessed. Serum from baseline and the 24-week follow-up were isolated from whole blood following clotting, centrifuged and immediately stored at $-80^{\circ} \mathrm{C}$ until thawed for further analysis. Pre-collected sera were used for apolipoprotein assessment. ApoA1 and ApoB were determined by a turbidimetric immunoassay test (ASSEL s.r.l., Rome, Italy). Sera containing antigen were added to a solution with a specific antibody that triggered a reaction resulting in turbidity. It was measurable at $340 \mathrm{~nm}$ and appeared proportional to concentration of either ApoA1 or Apo B in the sample. Serum $\operatorname{Lp}(\mathrm{a})$ concentration was determined by latex immuno turbidimetric method [ $\mathrm{Lp}(\mathrm{a})$ latex ABCO Diagnostic s.r.l.]. When the sample was mixed with appropriate buffer and latex particles coated with anti-Lp(a), $\mathrm{Lp}(\mathrm{a})$ reacted with antibodies leading to agglutination of latex particles. This agglutination was detected as a turbidity change $(620 \mathrm{~nm})$ proportional to $\mathrm{Lp}(\mathrm{a})$ concentration in the sample.

\section{Statistical analysis}

An expert and specifically trained biostatistician performed the statistical analysis. All samples were encoded into a dedicated database. Descriptive statistical analyses were developed at baseline and at the 24-week follow-up. Data are expressed as the mean $[ \pm$ standard deviation (sd)], median (with range) or delta values as applicable. Confidence interval (CI) is presented where appropriate. Significant differences between variables were calculated with non-parametric tests. $\chi^{2}$ or Fisher's exact test was used for categorical while Kruskal-Wallis for continuous variables. Wilcoxon tes t was utilized to assess tendencies and specific rank test for significance. Logistic Regression was performed for searching the potential predictors of altered lipid metabolism. A p value less than 0.05 was considered significant for all tests. SPSS ${ }^{\circledR}$ software version 20.0 (MJ Norusis, Chicago, US) was used for all statistical analyses.

The laboratory tests described in the present study are not experimental, but they can be performed according to the physician's decision. However, patients had given informed consent to utilize their stored sera for planned controls. 


\section{RESULTS}

\section{Patient population}

During the study period, 115 patients were treated with DAA, and 100 fulfilled the established criteria (Figure 1). Main clinical patterns of entire cohort are reported in table 1 .

At the beginning of study period, 2 patients were taking lipid-lowering therapy (rosuvastatin; all with stable dosage in the last three months before enrollment) and 21 anti-diabetics (metformin; all with stable dosage in the last three months before enrollment).

Significant modifications in liver function with regards to albumin, bilirubin, prothrombin time, Model for Endstage Liver Disease or Child-Turcotte-Pugh score were not registered during the study period.

Metabolic changes from baseline to the 24-week follow-up are reported in table 2. Significant modifications in type 2 diabetes mellitus status, arterial hypertension, and MS were not observed. Body mass index values remained stable during the study period. During the study period, no patient modified the anti-diabetic or the lipidlowering therapy. Patients did not change their lifestyle (diet and aerobic exercise).

The mean glycemia values did not change while the mean insulin levels and HOMA-IR decreased (from 16.5 \pm 7.3 to $11.6 \pm 5.8, \mathrm{p}<0.001$ and from $3.8 \pm 1.9$ to $2.7 \pm$ $1.5, \mathrm{p}<0.001$, respectively). The median insulin level decreased from 16 (range 2-38) to 10 (range 0.5-31) $\mu \mathrm{IU} / \mathrm{mL}$ and HOMA-IR from 3.5 (range 0.4-9.3) to 2.3 (range 0.38.1) (Figure 2). The insulin levels declined in $69 \%$ of patients while the HOMA-IR was decreased in $78 \%$ of

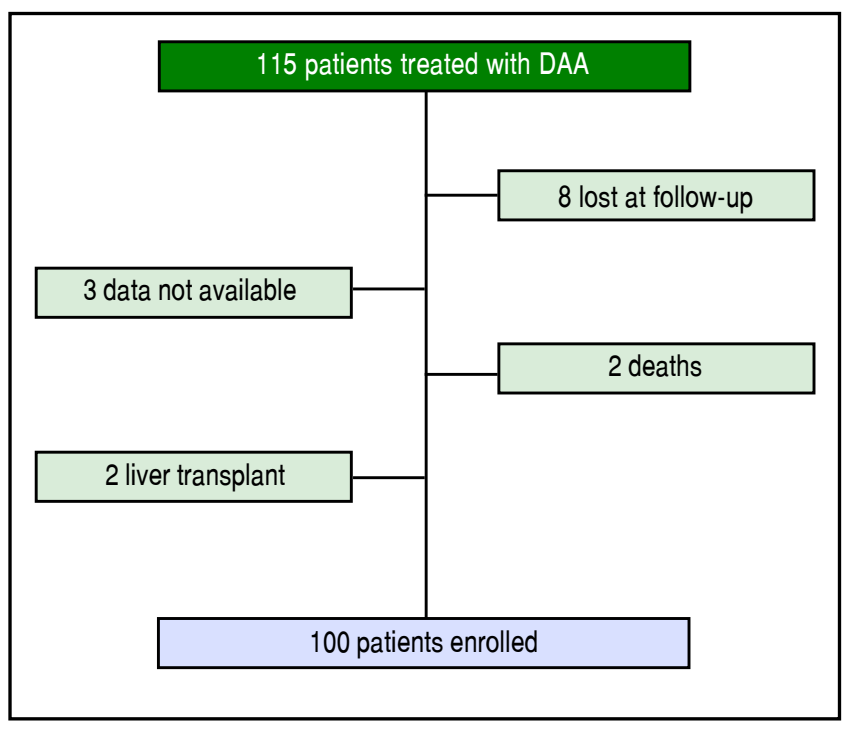

Figure 1. Flow chart. Selection of patients.
Table 1. Baseline features of the entire study population.

\begin{tabular}{|c|c|}
\hline $\mathrm{N}$ & 100 \\
\hline $\begin{array}{l}\text { Male } \\
\text { Age (years, mean } \pm \text { SD) } \\
\text { BMI }(\mathrm{kg} / \mathrm{m} 2)(\text { mean } \pm S D)\end{array}$ & $\begin{array}{c}59 \\
64 \pm 12 \\
26.2 \pm 4.1\end{array}$ \\
\hline $\begin{array}{l}\text { Genotype } \\
\text { 1a } \\
1 \mathrm{~b} \\
2 \\
3 \\
4 \\
\text { Naïve }\end{array}$ & $\begin{array}{c}10 \\
59 \\
10 \\
16 \\
5 \\
50\end{array}$ \\
\hline $\begin{array}{l}\text { Fibrosis stage } \\
\text { F1 } \\
\text { F2 } \\
\text { F3 } \\
\text { F4 } \\
\text { CTP B } \\
\text { MELD (mean } \pm \text { SD) } \\
\text { Low HCV-RNA }(<6 \times 105 \mathrm{UL} / \mathrm{mL})\end{array}$ & $\begin{array}{c}4 \\
2 \\
13 \\
81^{*} \\
6 \\
8 \pm 2 \\
40\end{array}$ \\
\hline $\begin{array}{l}\text { Basal metabolic features } \\
\text { Arterial hypertension } \\
\text { T2DM } \\
\text { MS }\end{array}$ & $\begin{array}{l}35 \\
16 \\
19\end{array}$ \\
\hline $\begin{array}{l}\text { DAA regimen } \\
\text { SOF } \pm \text { RBV } \\
\text { SOF/LPV } \pm \text { RBV } \\
\text { SOF/DCV } \pm \text { RBV } \\
\text { SOF/SMV } \pm R B V \\
\text { OBV/PTV/RTV + DSV } \pm \text { RBV } \\
\text { OBV/PTV/RTV } \pm \text { RBV } \\
\text { RBV } \\
\text { Length therapy } 12 / 24 \text { week, } n \\
\text { SVR } \\
\text { NR } \\
\text { Relapser }\end{array}$ & $\begin{array}{c}20 \\
11 \\
6 \\
43 \\
17 \\
3 \\
83 \\
65 / 35 \\
93 \\
0 \\
7\end{array}$ \\
\hline
\end{tabular}

* Diagnosis of cirrhosis was performed with liver biopsy in 10 patients and with transient elastography in the other subjects. BMI: Body mass index. CTP: Child-Turcotte-Pugh. MELD: Model for End-stage Liver Disease. HCV: Hepatitis C virus. T2DM: Type 2 diabetes mellitus. MS: Metabolic syndrome. SOF: Sofosbuvir. RBV: Ribavirin. LPV: Ledipasvir. DCV: Daclatasvir. SMV: Simeprevir. OBV: Ombitasvir. PTV: Paritaprevir. RTV: Ritonavir. DSV: Dasabuvir. SVR: Sustained virological response. NR: Non responder.

patients. The mean delta HOMA-IR (week 24 - baseline) was $-1.1 \pm 1.6$, while the median value was -0.7 (range -6.6 - +2.8) (Figure 3).

The HDL and triglyceride levels did not change over time, but the mean total cholesterol and LDL values were significantly increased (from $154 \pm 34$ to $170 \pm 37 \mathrm{mg} / \mathrm{dL}$, $\mathrm{p}<0.001$ and from $80 \pm 26$ to $102 \pm 34 \mathrm{mg} / \mathrm{dL}, \mathrm{p}<0.001$, respectively). The median total cholesterol increased from 151 (range 81-249) to 170 (range 75-249) $\mathrm{mg} / \mathrm{dl}$, and the LDL increased from 75 (range 25-148) to 103 (range 22- 
Table 2. Metabolic changes from baseline to week 24 of follow-up.

\begin{tabular}{|c|c|c|c|}
\hline & $\begin{array}{c}\text { Baseline } \\
\text { Mean } \pm \text { SD }\end{array}$ & $\begin{array}{l}\text { Week } 24 \mathrm{FU} \\
\text { Mean } \pm \text { SD }\end{array}$ & $\begin{array}{c}\text { Wilcoxon } \\
\text { P value }\end{array}$ \\
\hline Glycaemia (mg/dL) & $92 \pm 19$ & $92 \pm 22$ & 0.356 \\
\hline Insulin $(\mu \mathrm{IU} / \mathrm{dL})$ & $16.5 \pm 7.3$ & $11.6 \pm 5.8$ & 0.000 \\
\hline HOMA-IR & $3.8 \pm 1.9$ & $2.7 \pm 1.5$ & 0.000 \\
\hline Total cholesterol (mg/dL) & $154 \pm 34$ & $170 \pm 37$ & 0.000 \\
\hline $\mathrm{LDL}(\mathrm{mg} / \mathrm{dL})$ & $80 \pm 26$ & $102 \pm 34$ & 0.000 \\
\hline $\mathrm{HDL}(\mathrm{mg} / \mathrm{dL})$ & $52 \pm 19$ & $54 \pm 15$ & 0.328 \\
\hline LDL/HDL ratio & $1.79 \pm 1.10$ & $2.08 \pm 1.05$ & 0.000 \\
\hline Non-HDL cholesterol (mg/dL) & $102 \pm 29$ & $116 \pm 35$ & 0.000 \\
\hline Triglycerides (mg/dL) & $98 \pm 49$ & $100 \pm 110$ & 0.075 \\
\hline ApoA1 & $182 \pm 39.2$ & $164.28 \pm 30.8$ & 0.000 \\
\hline ApoB & $84.2 \pm 26.5$ & $84.4 \pm 22.8$ & 0.903 \\
\hline АроВ/АроA1 & $0.48 \pm 0.18$ & $0.53 \pm 0.18$ & 0.000 \\
\hline $\operatorname{Lp}(a)$ & $5.6 \pm 6.5$ & $9.8 \pm 11.5$ & 0.000 \\
\hline BMI $\left(\mathrm{kg} / \mathrm{m}^{2}\right)$ & $26.2 \pm 4.1$ & $26 \pm 4$ & 0.146 \\
\hline
\end{tabular}

FU: follow-up. SD: standard deviation. HOMA-IR: Homeostatic Model Assessment of Insulin Resistance. LDL: Low density lipoprotein. HDL: High density lipoprotein. ApoA1: Apolipoprotein A1. ApoB: Apolipoprotein B. Lp(a): Lipoprotein (a). BMI: Body mass index.

A

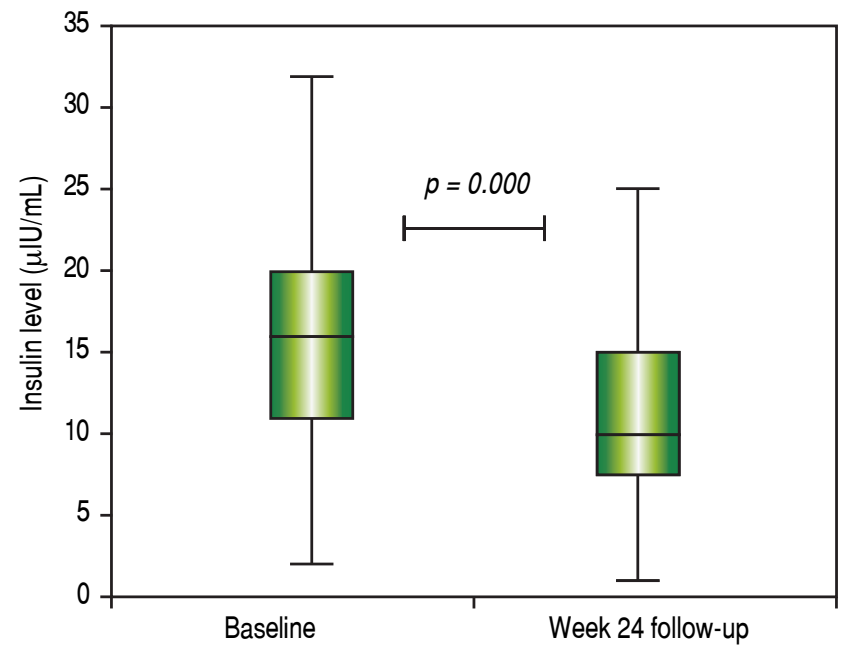

B

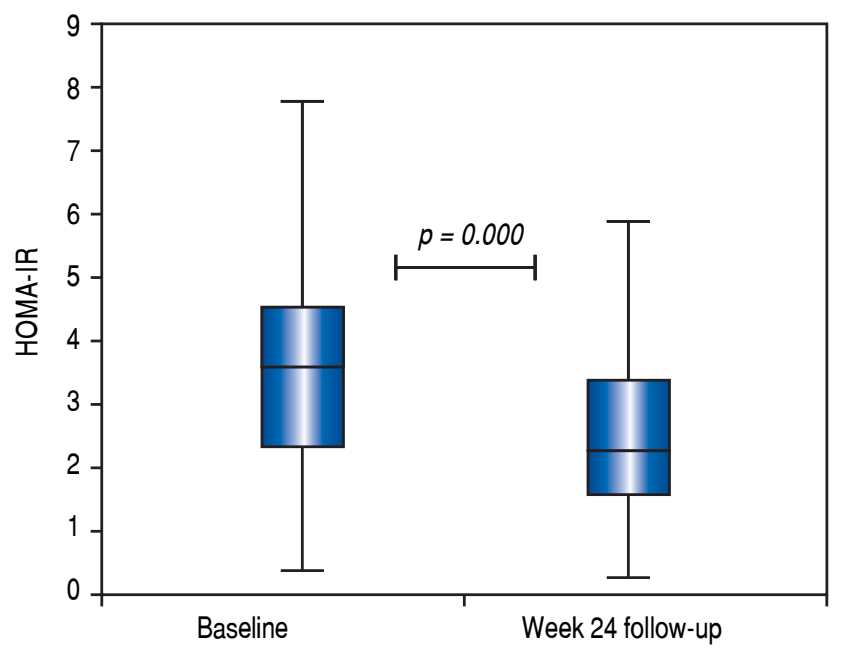

Figure 2. Distribution of insulin and HOMA-IR at baseline and 24-week of follow-up. Horizontal bar inside the box represents median values (HOMA-IR, homeostatic model assessment of insulin resistance).

179) $\mathrm{mg} / \mathrm{dL}$. The total cholesterol was elevated in $71 \%$ of subjects, while the LDL concentration was increased in $73 \%$. The mean delta LDL (week 24 - baseline) was $+23 \pm$ $32 \mathrm{mg} / \mathrm{dL}$, while the median value was +24 (range $-62-$ $+98) \mathrm{mg} / \mathrm{dL}$. The mean LDL/HDL ratio was significantly increased (from $1.79 \pm 1.10$ to $2.08 \pm 1.05 \mathrm{mg} / \mathrm{dL}, \mathrm{p}<$ 0.001). The median LDL/HDL ratio increased from 1,55 (range 0.59-8.13) to 1.83 (range 0.41-6.07). The LDL/HDL ratio was elevated in $68 \%$ of the cases. The mean delta
LDL/HDL ratio was $+0.28 \pm 1.03 \mathrm{mg} / \mathrm{dL}$, while the median value was +0.24 (range $-5.23-+3.08) \mathrm{mg} / \mathrm{dL}$. The mean non-HDL cholesterol increased from $102 \pm 29$ to $116 \pm 35 \mathrm{mg} / \mathrm{dL}(\mathrm{p}<0.001)$. The median values were 97 (range 42-206) and 114 (range 39-204) mg/dL, respectively (Figure 4). The non-HDL cholesterol was increased in $67 \%$ of patients. The mean delta was $+14 \pm 32 \mathrm{mg} / \mathrm{dL}$, while the median value was +13 (range $-78-+102$ ) $\mathrm{mg}$ / dL (Figure 5). 


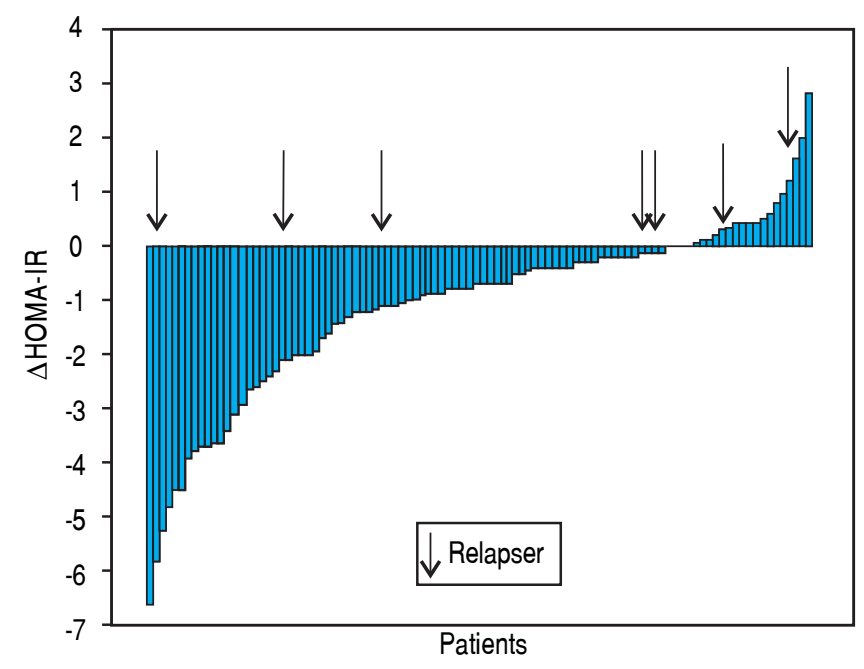

Figure 3. Individual delta HOMA-IR. Each square represents a patient. Arrows indicated relapsers (HOMA-IR, homeostatic model assessment of insulin resistance).

\section{Apolipoprotein modifications}

Changes in apolipoprotein levels from baseline to the 24-week follow-up are reported in table 2. During the study period, the ApoB levels did not change. The mean ApoA1 levels significantly decreased from $182 \pm 39.2$ to $164 \pm 31 \mathrm{mg} / \mathrm{dL}(\mathrm{p}<0,001)$, and the median declined from 178 (range 74-277) to 160 (range 93-236) $\mathrm{mg} / \mathrm{dL}$. The ApoA1 levels decreased in $75 \%$ of cases, and the mean delta ApoA1 was $-17.7 \pm 33.7 \mathrm{mg} / \mathrm{dL}$ (median value -19 , range $105-+65 \mathrm{mg} / \mathrm{dL}$ ). The mean ApoB/ApoA1 ratio increased from $0.48 \pm 0.18$ to $0.53 \pm 0.18 \mathrm{mg} / \mathrm{dL}(\mathrm{p}<0.001)$, and median ApoB/ApoA1 ratio increased from 0.45 (range 0.231.18 ) to 0.50 (range $0.27-1.14$ ) mg/dL. The ApoB/ApoA1 ratio was increased in $69 \%$ of subjects with a delta ApoB/ ApoA1 ratio of $+0.05 \pm 0.14 \mathrm{mg} / \mathrm{dL}$ (median +0.06 , range $0.37-+0.38 \mathrm{mg} / \mathrm{dL})$.

The mean $L p(a)$ value increased from $5.6 \pm 6.5$ to $9.8 \pm$ $11.5 \mathrm{mg} / \mathrm{dL}$ ( $\mathrm{p}<0.001$ ), while the median value increased from 3.3 (range 0.3-30.4) to 5.7 (range 0.5-69.5) $\mathrm{mg} / \mathrm{dL}$. The $\mathrm{Lp}(\mathrm{a})$ was increased in $84 \%$ of patients, and the delta $\mathrm{Lp}(\mathrm{a})$ was $+4.2 \pm 6.9 \mathrm{mg} / \mathrm{dL}$ (median +1.7 , range -0.5 $+43.5)$ (Figures 6 and 7).

\section{Responders to antivirals vs. relapsers}

Patients achieving SVR at 24 weeks after the end of treatment and subjects with virological relapse were compared for all patterns. Any significant difference was observed between the two subgroups (Table 3). As shown in table 4, changes in glucose and lipid profile were observed in patients with SVR but not in relapsers. Concerning mean delta values, relevant discrepancies were found in delta LDL/HDL ratio $(+0.3 \pm 1.1$ in responders $v s .-0.05$ \pm 0.69 in relapsers, $\mathrm{p}=0.188)$, delta non-HDL cholesterol (+16 \pm 30 vs. $-6 \pm 51 \mathrm{mg} / \mathrm{dL}, \mathrm{p}=0,211)$, delta ApoA1 ($19 \pm 34$ vs. $+3 \pm 25 \mathrm{mg} / \mathrm{dL}, \mathrm{p}=0,065)$. However, the largest difference was observed in the delta ApoB/ApoA1 ratio $(+0.06 \pm 0.13 v$ s. $-1.1 \pm 0.19, \mathrm{p}=0.012)$ (Table 5). In figures 3,5 and 7 , we indicated the individual delta values of patients with virological relapse.

\section{Subanalysis of genotype 3 patients}

CHC infection is associated with onset of hepatic steatosis and a decrease of total cholesterol, LDL and apoB, and all these changes were more pronounced in GT3 patients. ${ }^{26}$ In our study cohort, there were no differences regarding the basal levels of lipids between patients with GT3 and the other patients with the exception of ApoA1, which was significantly lower in GT3 patients $(161 \pm 29$ vs. $186 \pm 40 \mathrm{mg} / \mathrm{dL}, \mathrm{p}=0.010)$. Delta ApoA1 was also drastically different $(-0.125 \pm 30 \mathrm{mg} / \mathrm{dL}$ in GT3 vs. $-21 \pm 33$ $\mathrm{mg} / \mathrm{dL}$ in the others, $\mathrm{p}=0.020$ ). Regarding the lipid changes from baseline to week 24 of the follow-up, when considering only patients with GT3 infection, there were significant modifications in the total cholesterol, LDL and Lp(a) levels (138 \pm 36 to $167 \pm 41 \mathrm{mg} / \mathrm{dL}, \mathrm{p}=0.021,73 \pm$ 25 to $107 \pm 32 \mathrm{mg} / \mathrm{dL}, \mathrm{p}=0.008$ and $8 \pm 8$ to $12 \pm 10 \mathrm{mg} /$ $\mathrm{dL}, \mathrm{p}=0.001$, respectively). Notably, other changes in the lipid profile were similar to those of the entire cohort, but these differences were not significant. In particular, the LDL/HDL ratio, non-HDL cholesterol, ApoB, and the ApoB/ApoA1 ratio showed an increasing trend while ApoA1 tended to decrease.

\section{Univariate and multivariate analyses for predictors of lipid alterations}

Univariate analysis for predictors of LDL increase indicated that RBV was the unique variable with significant $\mathrm{p}$ value [Odds Ratio (OR) 4.062, 95\% CI 1,371-12,035, $\mathrm{p}=$ $0.011]$. We then tested all variables for the predictive capacity of an increased LDL/HDL ratio. Again, only RBV emerged as a significant variable for the univariate analysis (OR 5.413, 95\% CI 1.782-16.441, $\mathrm{p}=0.003$ ). Considering the potential predictors for increases in non-HDL cholesterol, only RBV showed a p value < 0.1 (OR 5,083, 95\% CI 1.679-15.390, $\mathrm{p}=0.004$ ).

Concerning the predictive factors for decreases in ApoA1, male gender and SVR achievement showed significance in the univariate analysis (OR 3.556, 95\% CI 1,379$9,169, \mathrm{p}=0.009$ and OR 4.571, 95\% CI 0.947-22.059, $\mathrm{p}=$ 0.058 , respectively). At the multivariate analysis, only male gender emerged as independent predictor (OR 3,434, 95\% 


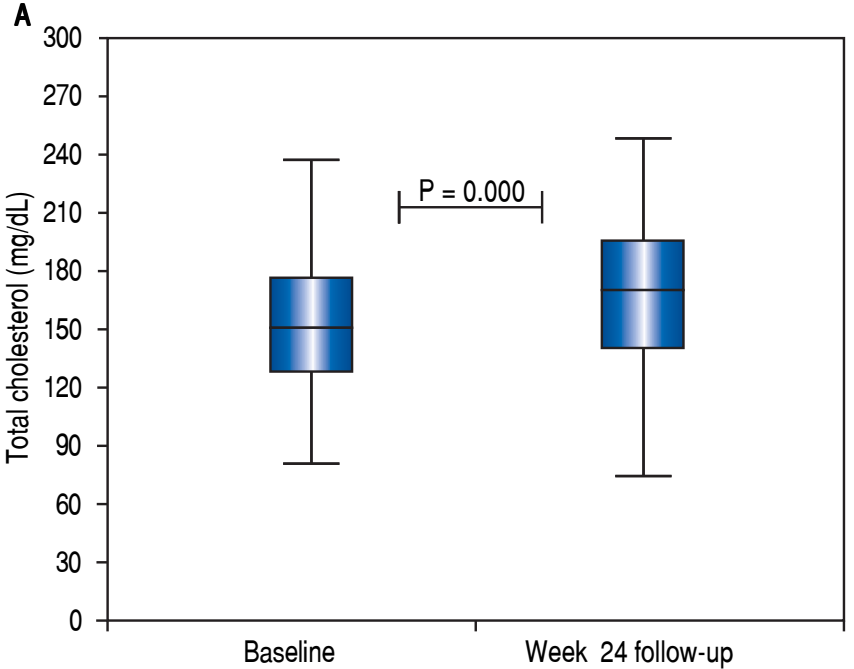

C

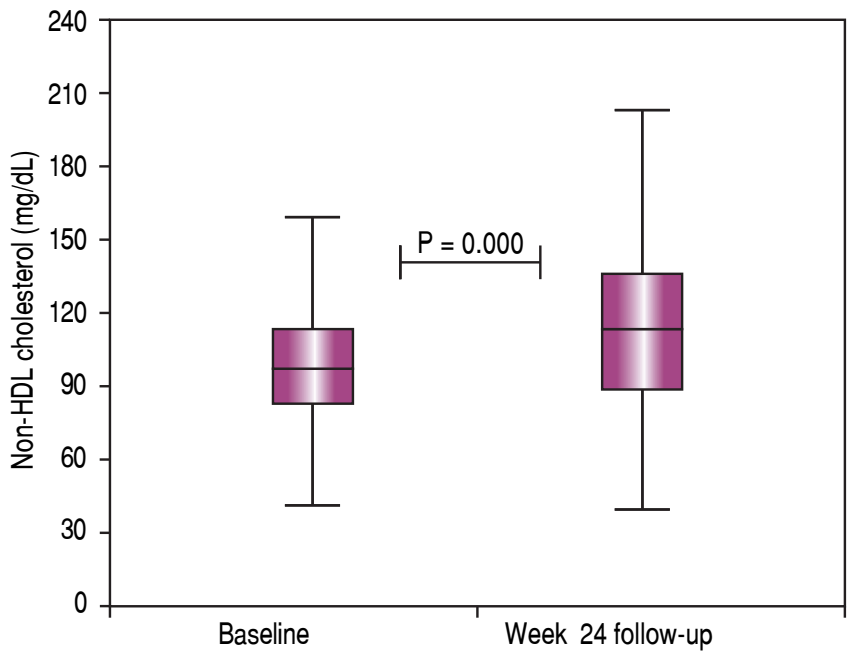

B

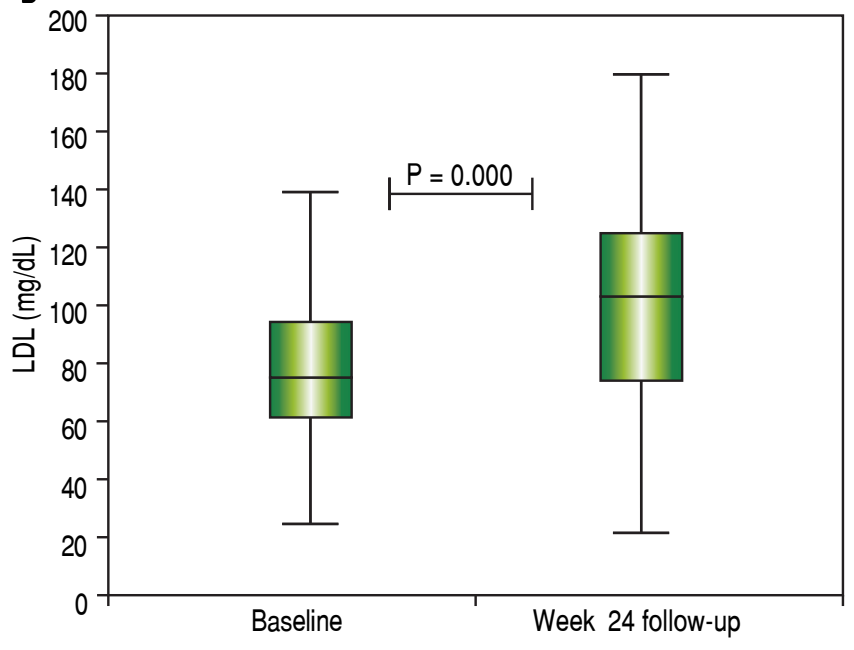

D

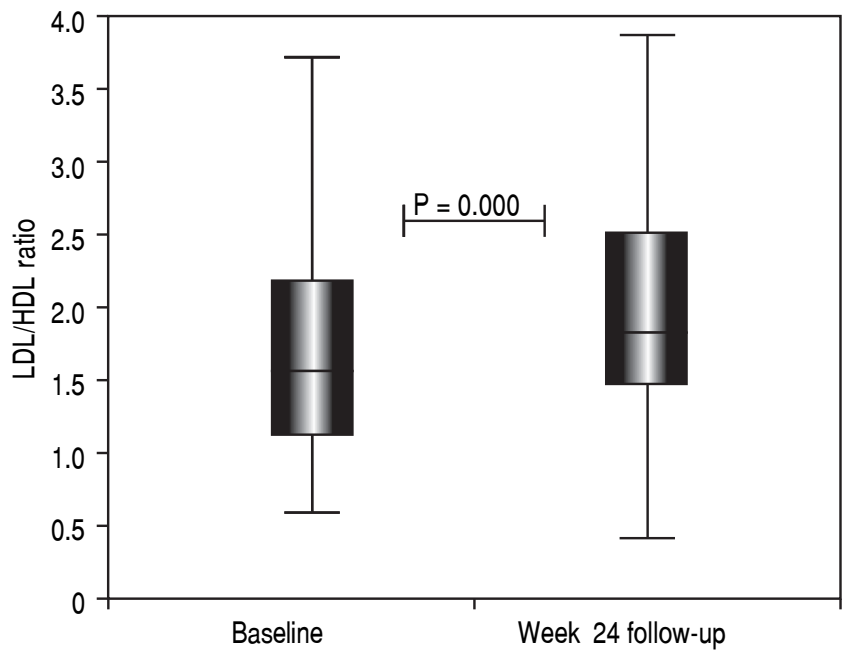

Figure 4. Distribution of total cholesterol, LDL, LDL/HDL ratio and Non-HDL cholesterol at baseline and 24-week of follow-up. Horizontal bar inside the box represents median values (LDL: Low-density lipoprotein. HDL: High-density lipoprotein).

CI 1,310-9,002, p=0.012) (Table 6). Male gender and SVR were significant at univariate analysis for predictors of ApoB/ApoA1 ratio increase (OR 2.277, 95\% CI 0,960-5,400, $\mathrm{p}=0.062$ and OR 6.442, 95\% CI 1,175-35.307, $\mathrm{p}=0.032$, respectively). The multivariate test failed to identify significant factor (Table 7).

Univariate analysis for predictors for increased $\mathrm{Lp}(\mathrm{a})$ indicated that male gender, advanced fibrosis and the use of RBV had p values < 0.1 (OR 2.849, 95\% CI 0.944-8.602, $\mathrm{p}=0.063$, OR 3.277, 95\% CI 1.015-10.581, p $=0.047$ and OR 3.920, 95\% CI 1.206-13.144, $\mathrm{p}=0.023$, respectively). The multivariate analysis showed that RBV use was an independent predictor of $\mathrm{Lp}(\mathrm{a})$ increase (OR 3,982, 95\% CI 1.206-13.144, $\mathrm{p}=0.023$ ) (Table 8).

\section{DISCUSSION}

Patients with $\mathrm{CHC}$ show a reduction of total cholesterol, LDL and ApoB levels ${ }^{6}$ but also a worsening of glucose metabolism. ${ }^{7}$ Few studies described the impact of DAA on glucose and lipid metabolism, and available data are incomplete and contradictory. ${ }^{11,14-16}$ Notably, Hashimoto, et al. ${ }^{16}$ suggested that the rapid suppression of HCV core proteins due to DAA may lead to a deregulation of host lipid metabolism that manifests as a decrease of lipid droplet production in $\mathrm{HCV}$-infected liver cells and a large rebound of circulating LDL.

This negative impact on lipid metabolism is either absent or underestimated in cases of IFN-based therapy 

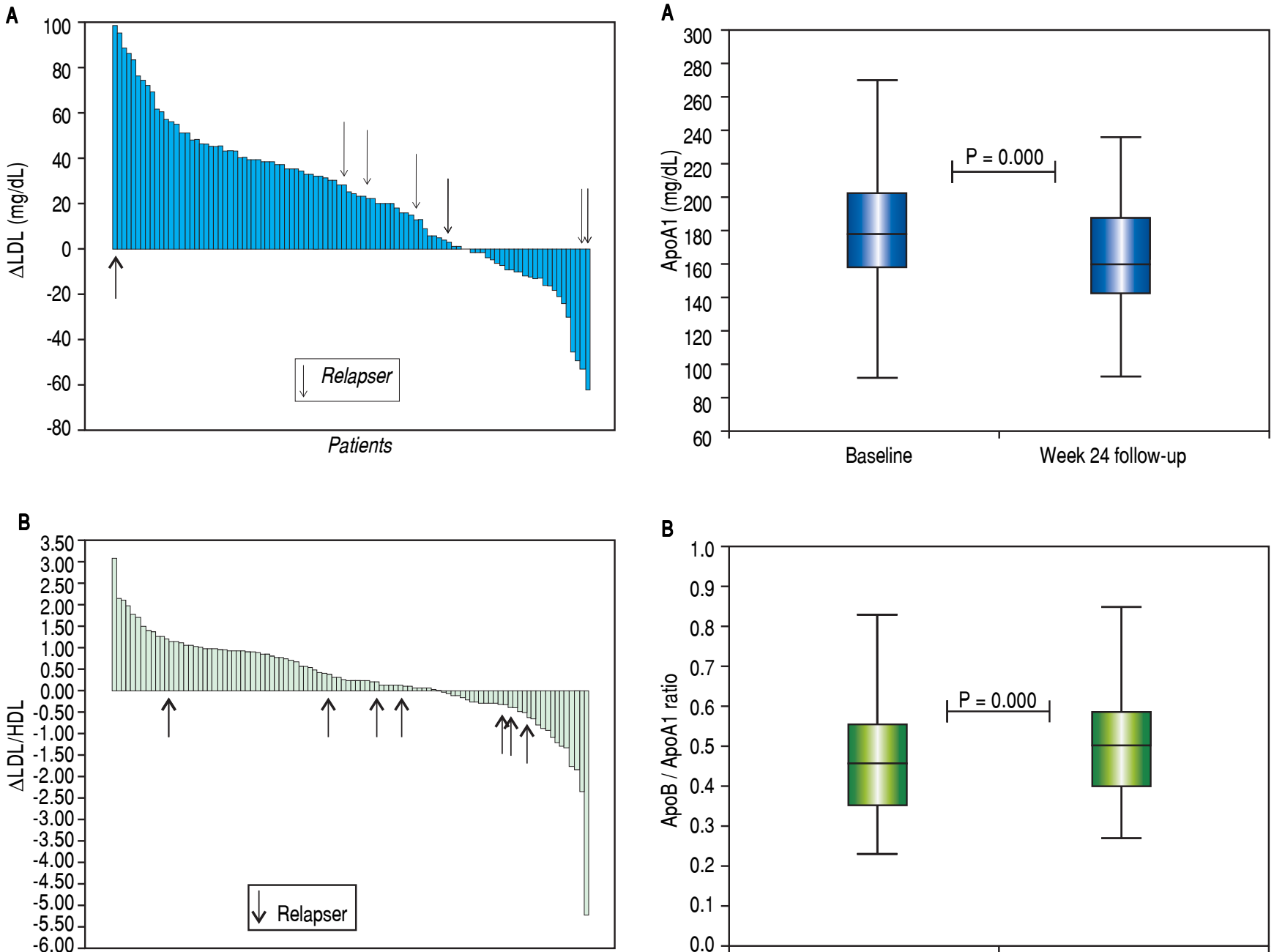

Patients

B

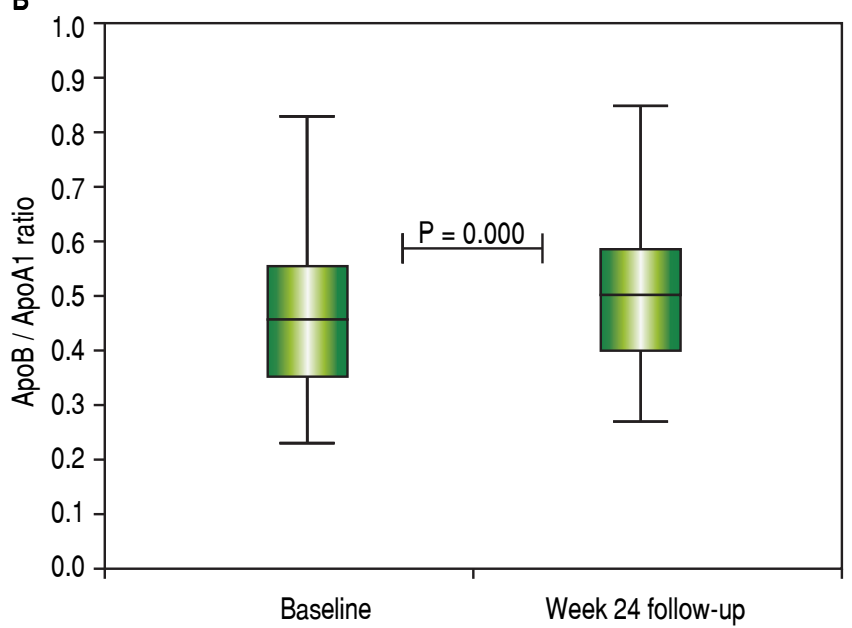

C

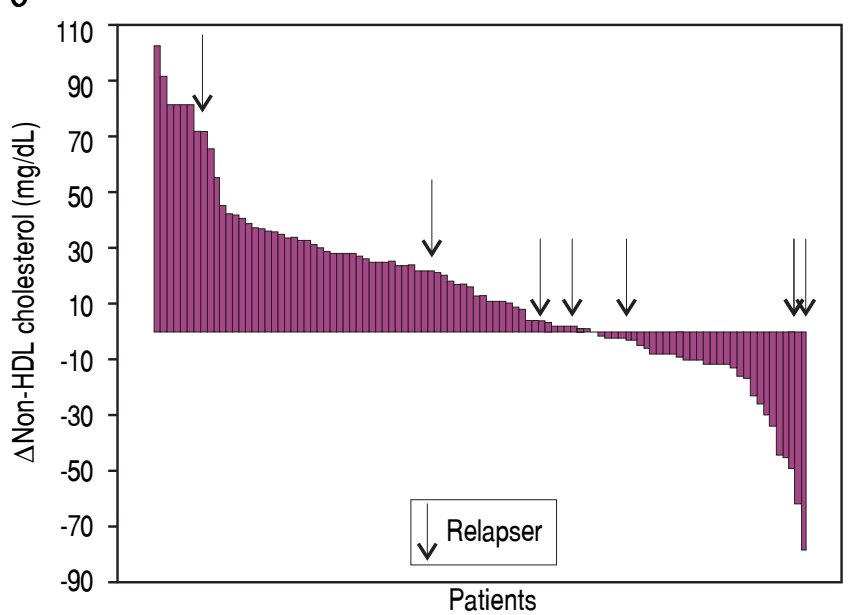

Figure 5. Individual delta $L D L, L D L / H D L$ ratio and Non- $H D L$ cholesterol value. Each square represents a patient. Arrows indicated relapsers (LDL, low-density lipoprotein; HDL, high-density lipoprotein).

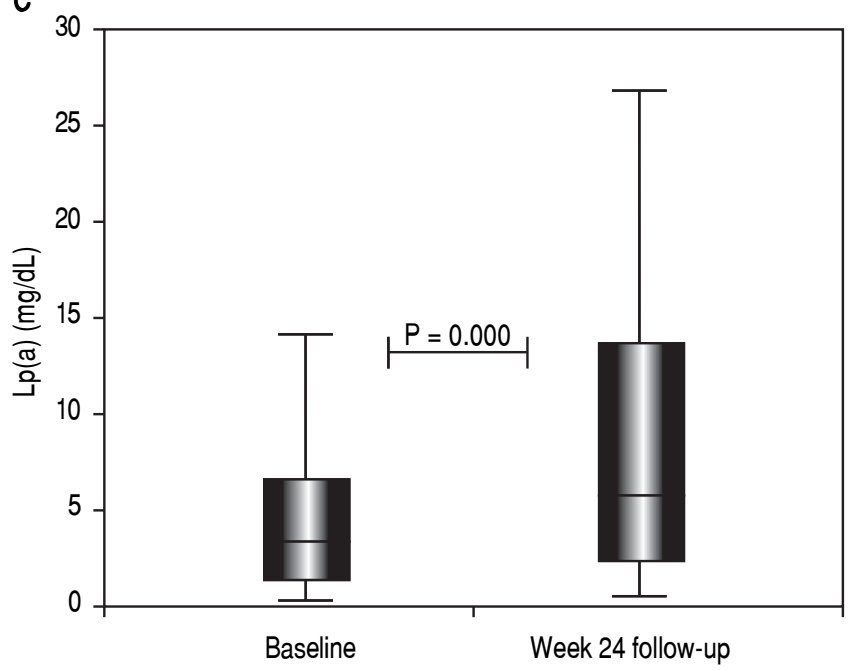

Figure 6. Distribution of $A p o A 1, A p o B / A p o A 1$ ratio and $L p(a)$ at baseline and 24-week of follow-up. Horizontal bar inside the box represents median values [ApoA1, apolipoprotein; ApoB, apolipoprotein B; Lp(a), lipoprotein (a)]. 
A

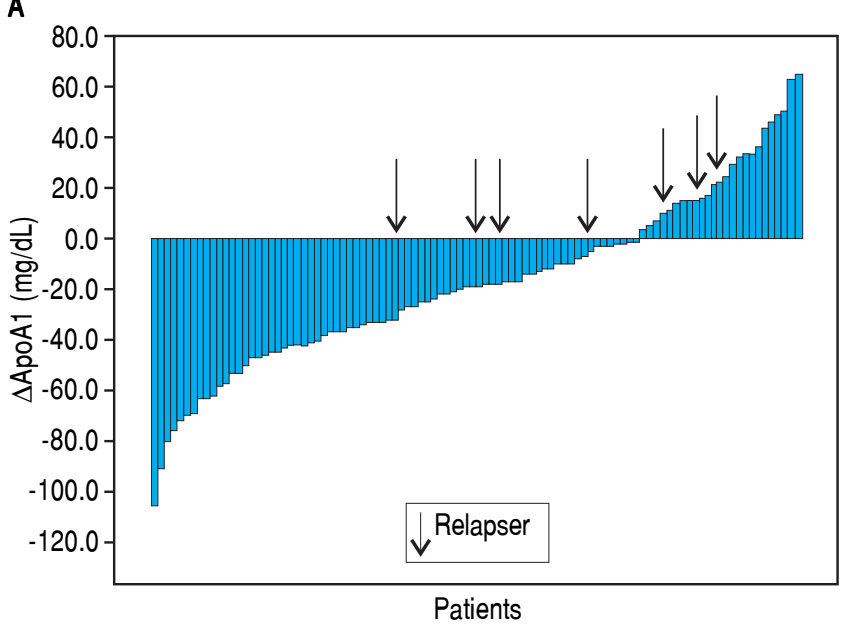

B

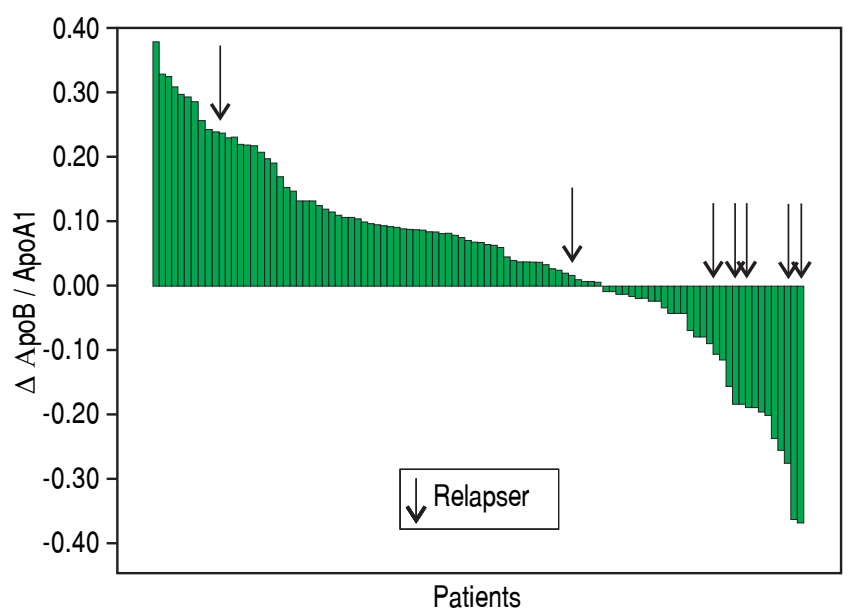

C

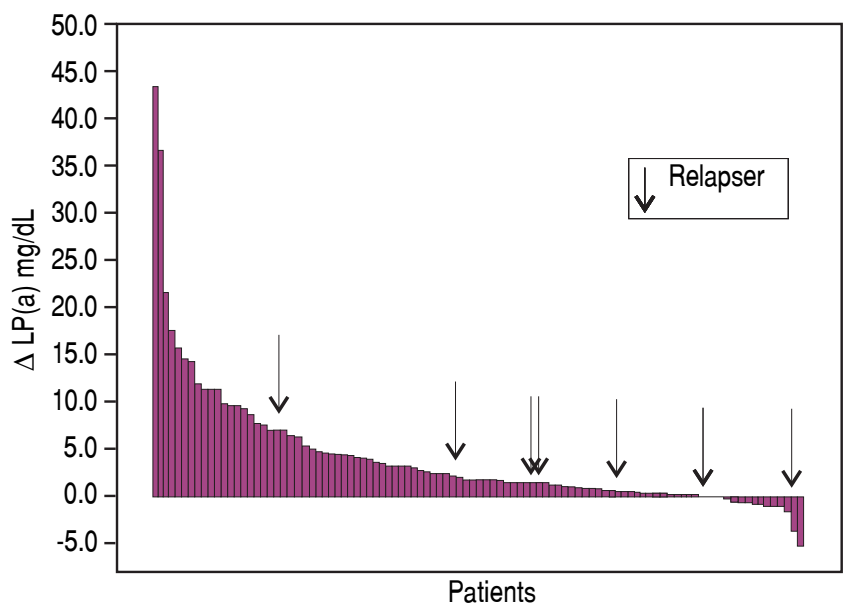

Figure 7. Individual delta $A p o A 1$, delta $A p o B / A p o A 1$ ratio and delta $L p(a)$ value. Each square represents a patient. Arrows indicated the relapsers [ApoA1, apolipoprotein; ApoB, apolipoprotein B; Lp(a), lipoprotein (a)]. probably due to the frequent presence of anorexia. ${ }^{27} \mathrm{In}$ general, the well-known differences between IFN-based therapy and DAA make these approaches incomparable with regard to metabolic changes.

We proposed a real-life study with a complete analysis of glucose and lipid changes over a follow-up period through 24 weeks after the end of treatment. To estimate the apolipoprotein levels is the most appropriate way for studying the effect of DAA on lipid metabolism. ${ }^{19,20}$ Notably, we examined the $\operatorname{Lp}(\mathrm{a})$ that represents an independent drug-resistant marker of CV disease. ${ }^{22}$ Moreover, we evaluated other relevant patterns of the lipid profile such as the LDL/HDL ratio, the ApoB/ApoA1 ratio, and nonHDL cholesterol levels, and we recorded some potential confounding factors such as body mass index, lifestyle changes, drug modifications and liver function tests.

We demonstrated that viral clearance due to DAA led to significant decrease of HOMA-IR, rise of total cholesterol, LDL, LDL/HDL ratio and non-HDL cholesterol regardless of DAA regimen or fibrotic stage. Furthermore, patients achieving SVR showed a relevant decrease in the ApoA1 levels and an increase in the ApoB/ApoA1 ratio. Finally, $L p(a)$ was significantly elevated in patients who achieved SVR. All the changes in glucose and lipid metabolism occurred without modifications of body mass index, changes of metabolic drug regimens or variations of lifestyle. In particular, regarding lipid-lowering drugs, as expected, at the beginning of the study period only 2 patients were taking them (both rosuvastatin). The reported alterations of lipid profile were registered also in that two patients but dedicated larger studies will be necessary to analyze the possible specific role of statins during or after DAA therapy. Regarding anti-diabetic drugs, at the start of study period 21 patients were taking anti-diabetic medication (all metformin). The favorable modifications of the glucose metabolism in terms of insulin and HOMA were registered also in patients on anti-diabetic therapy. Notably, no patient changed his therapy during the study period neither as kind of drug nor as dosage.

Cholesterol levels can be considered an important index of liver synthesis, and viral clearance may lead to recovery of liver function. ${ }^{28}$ Indeed, we evaluated albumin, bilirubin, prothrombin time, Model for End-stage Liver Disease and Child-Turcotte-Pugh score, not recording any significant change. Remarkably, we demonstrated that the modifications of the glucose and lipid profile were absent in patients with virological relapse, thus suggesting a potential role of HCV clearance. Markedly, the few number of relapsers makes actually impossible to draw solid conclusions about this subgroups.

All HCV patients present a decrease of total cholesterol, LDL and ApoB, and these changes were more pronounced in GT3 subjects with respect to other GT. ${ }^{26}$ For 
Table 3. Main baseline features of patients subdivided according to virological response.

\begin{tabular}{|c|c|c|c|}
\hline & Responders & Relapsers & $\chi^{2} / \mathrm{MW}-\mathrm{U}$ \\
\hline $\begin{array}{l}\text { Male } n(\%) \\
\text { Age (years, mean } \pm \text { SD) } \\
\text { BMI }(\mathrm{Kg} / \mathrm{m} 2)(\text { mean } \pm \mathrm{SD})\end{array}$ & $\begin{array}{c}93 \\
56(60.2) \\
64 \pm 12 \\
26 \pm 4\end{array}$ & $\begin{array}{c}7 \\
3(42.9) \\
62 \pm 14 \\
25.4 \pm 2.9\end{array}$ & $\begin{array}{l}P \text { value } \\
0.304 \\
0.705 \\
0.724\end{array}$ \\
\hline $\begin{array}{l}\text { Genotype n (\%) } \\
\text { 1a } \\
1 \mathrm{~b} \\
2 \\
3 \\
4\end{array}$ & $\begin{aligned} 9 & (9.7) \\
56 & (60.1) \\
9 & (9.7) \\
14 & (15.1) \\
5 & (5.4)\end{aligned}$ & $\begin{array}{l}1(14.3) \\
3(42.8) \\
1(14.3) \\
2(28.6) \\
0(0)\end{array}$ & $\begin{array}{l}0.533 \\
0.304 \\
0.533 \\
0.311 \\
0.690\end{array}$ \\
\hline $\begin{array}{l}\text { Naïve } n(\%) \\
\text { Fibrosis stage F4 n (\%) } \\
\text { CTP B } n(\%) \\
\text { MELD (mean } \pm \text { SD) } \\
\text { Low HCV-RNA }(<6 \times 105 \mathrm{UI} / \mathrm{mL}) \mathrm{n}(\%)\end{array}$ & $\begin{array}{c}48(51.6) \\
75(80.6) \\
6(6.5) \\
8 \pm 2 \\
38(40.9)\end{array}$ & $\begin{array}{l}2(28.6) \\
6(85.7) \\
0(0) \\
8 \pm 2 \\
2(28.6)\end{array}$ & $\begin{array}{l}0.218 \\
0.602 \\
0.639 \\
0.818 \\
0.415\end{array}$ \\
\hline $\begin{array}{l}\text { Basal metabolic values (mean } \pm \mathrm{SD}) \\
\text { Glycaemia }(\mathrm{mg} / \mathrm{dL}) \\
\text { Insulin }(\mu \mathrm{lU} / \mathrm{mL}) \\
\text { HOMA-IR } \\
\text { Total cholesterol }(\mathrm{mg} / \mathrm{dL}) \\
\text { LDL }(\mathrm{mg} / \mathrm{dL}) \\
\text { HDL }(\mathrm{mg} / \mathrm{dL}) \\
\text { Triglycerides }(\mathrm{mg} / \mathrm{dL}) \\
\text { Arterial hypertension } \mathrm{n}(\%) \\
\text { T2DM } \mathrm{n}(\%) \\
\text { MS }\end{array}$ & $\begin{array}{c}92 \pm 20 \\
16 \pm 7 \\
3,8 \pm 2 \\
155 \pm 34 \\
80 \pm 26 \\
53 \pm 19 \\
96 \pm 48 \\
31(33) \\
16(17.2) \\
16(17.2)\end{array}$ & $\begin{array}{c}85 \pm 11 \\
19 \pm 7 \\
3,9 \pm 1.7 \\
142 \pm 38 \\
75 \pm 26 \\
42 \pm 18 \\
120 \pm 48 \\
4(57.1) \\
0(0) \\
3(42.9)\end{array}$ & $\begin{array}{l}0.486 \\
0.368 \\
0.818 \\
0.256 \\
0.449 \\
0.224 \\
0.146 \\
0.192 \\
0.218 \\
0.194\end{array}$ \\
\hline $\begin{array}{l}\text { DAA regimen } n(\%) \\
\text { SOF } \pm R B V \\
\text { SOF/LPV } \pm \text { RBV } \\
\text { SOF/DCV } \pm \text { RBV } \\
\text { SOF/SMV } \pm \text { RBV } \\
\text { OBV/PTV/RTV + DSV } \pm R B V \\
\text { OBV/PTV/RTV } \pm R B V \\
\text { RBV } n(\%) \\
\text { Length therapy } 12 / 24 \text { week } n(\%)\end{array}$ & $\begin{array}{c}17(18.3) \\
11(11.8) \\
6(6.5) \\
39(41.9) \\
17(18.3) \\
3(3.2) \\
77(82.8) \\
61 / 32(65.6 / 34.4)\end{array}$ & $\begin{array}{c}3(42.9) \\
0(0) \\
0(0) \\
4(57.1) \\
0(0) \\
0(0) \\
6(85.7) \\
4 / 3(57.1 / 42.9)\end{array}$ & $\begin{array}{l}0.141 \\
0.430 \\
0.639 \\
0.345 \\
0.259 \\
0.803 \\
0.660 \\
0.469\end{array}$ \\
\hline
\end{tabular}

ఒ2: Chi square. MW-U: Mann-Whitney U test. BMI: Body mass index. CTP: Child-Turcotte-Pugh. MELD: Model for End-stage Liver Disease. HCV: Hepatitis C virus. HOMA-IR: Homeostatic Model Assessment of Insulin Resistance. LDL: Low Density Lipoprotein. HDL: High Density Lipoprotein. T2DM: Type 2 diabetes mellitus. MS: Metabolic syndrome. SOF: Sofosbuvir. RBV: Ribavirin. LPV: Ledipasvir. DCV: Daclatasvir. SMV: simeprevir. OBV: Ombitasvir. PTV: paritaprevir. RTV: Ritonavir. DSV: Dasabuvir. SVR: Sustained virological response. NR: Non responder.

this reason, we conducted a thorough analysis on this subgroup. Considering only patients with GT3, we found increases of total cholesterol, LDL and Lp(a) from baseline to week 24 of follow-up with significant $\mathrm{p}$ values. Other alterations of the lipid profile that were described among the whole cohort were present in the GT3 subpopulation but without statistical significance. Indeed, the worsening of the lipid profile due to DAA seemed to be less pronounced in the GT3 subgroup.

We demonstrated that the male gender represented an independent predictor of decreases in ApoA1, while the use of RBV could predict elevated Lp(a). It is well known that the male gender is a strong risk factor for both dyslipidemia and CV disease. ${ }^{29}$ In contrast, the effect of RBV on lipid alterations represents a partial novelty. In fact, Younossi, et al. ${ }^{23}$ reported that RBV use had an additive effect on ApoA1 and apolipoprotein E in comparison with RBVfree regimens. This decline in lipoprotein levels may cause an impairment of immune escape mechanism of $\mathrm{HCV}$, which could clarify the advantage of DAA/RBV with respect to RBV-free regimen in difficult-to-treat patients.

According to our data, RBV seemed to determine a major deregulation of the balance between virus and host 
Table 4. Metabolic changes from baseline to week 24 of follow-up according to virological response.

\begin{tabular}{|c|c|c|c|c|c|c|}
\hline & \multicolumn{3}{|c|}{ Responders $(n=93)$} & \multicolumn{3}{|c|}{ Relapsers $(n=7)$} \\
\hline & $\begin{array}{c}\text { Baseline } \\
\text { Mean } \pm \text { SD }\end{array}$ & $\begin{array}{l}\text { Week } 24 \text { FU } \\
\text { Mean } \pm \text { SD }\end{array}$ & $\begin{array}{l}\text { Wilcoxon } \\
\text { P value }\end{array}$ & $\begin{array}{c}\text { Baseline } \\
\text { Mean } \pm \text { SD }\end{array}$ & $\begin{array}{l}\text { Week } 24 \text { FU } \\
\text { Mean } \pm \text { SD }\end{array}$ & $\begin{array}{c}\text { Wilcoxon } \\
P \text { value }\end{array}$ \\
\hline Glycaemia (mg/dl) & $92 \pm 20$ & $92 \pm 23$ & 0.246 & $85 \pm 11$ & $91 \pm 19$ & 0.612 \\
\hline Insulin $(\mu \mathrm{lU} / \mathrm{dl})$ & $16 \pm 7$ & $12 \pm 6$ & 0.000 & $19 \pm 7$ & $12 \pm 8$ & 0.116 \\
\hline HOMA-IR & $3,8 \pm 2$ & $2.7 \pm 1,5$ & 0.000 & $3.9 \pm 1.7$ & $2.7 \pm 1.6$ & 0.236 \\
\hline Total cholesterol (mg/dl) & $154 \pm 34$ & $175 \pm 35$ & 0.000 & $142 \pm 37$ & $136 \pm 42$ & 0.735 \\
\hline $\operatorname{LDL}(\mathrm{mg} / \mathrm{dl})$ & $80 \pm 26$ & $103 \pm 33$ & 0.000 & $75 \pm 26$ & $82 \pm 44$ & 0.612 \\
\hline $\mathrm{HDL}(\mathrm{mg} / \mathrm{dl})$ & $53 \pm 19$ & $55 \pm 15$ & 0.350 & $41 \pm 18$ & $42 \pm 14$ & 0.916 \\
\hline LDL/HDL & $1.8 \pm 1.1$ & $2.1 \pm 1$ & 0.000 & $2.2 \pm 1,3$ & $2.2 \pm 1.8$ & 0.866 \\
\hline Non-HDL cholesterol (mg/dl) & $102 \pm 29$ & $117 \pm 34$ & 0.000 & $100 \pm 32$ & $94 \pm 42$ & 0.866 \\
\hline Triglycerides $(\mathrm{mg} / \mathrm{dl})$ & $96 \pm 48$ & $101 \pm 114$ & 0.216 & $120 \pm 47$ & $88 \pm 38$ & 0.080 \\
\hline ApoA1 (mg/dl) & $184 \pm 38$ & $165 \pm 30.5$ & 0.000 & $150 \pm 45$ & $152 \pm 34$ & 0.799 \\
\hline ApoB (mg/dl) & $84.2 \pm 26.5$ & $85.7 \pm 21.8$ & 0.787 & $84 \pm 28$ & $66 \pm 29$ & 0.176 \\
\hline АроB/АpoA1 & $0.47 \pm 0.18$ & $0.53 \pm 0.17$ & 0.000 & $0.57 \pm 0.17$ & $0.45 \pm 0.26$ & 0.176 \\
\hline $\mathrm{Lp}(\mathrm{a})(\mathrm{mg} / \mathrm{dL})$ & $5.9 \pm 6.6$ & $10.2 \pm 11.7$ & 0.000 & $2.3 \pm 2.1$ & $3.9 \pm 3.4$ & 0.090 \\
\hline $\mathrm{BMI}\left(\mathrm{Kg} / \mathrm{m}^{2}\right)$ & $26.2 \pm 4.1$ & $26 \pm 4.1$ & 0.189 & $25.4 \pm 2.9$ & $25.1 \pm 2.9$ & 0.157 \\
\hline
\end{tabular}

FU: Follow-up. SD: Standard deviation. HOMA-IR: Homeostatic Model Assessment of Insulin Resistance. LDL: Low density lipoprotein. HDL: High density lipoprotein. ApoA1: Apolipoprotein A1. ApoB: apolipoprotein B. Lp(a): Lipoprotein (a). BMI: Body mass index.

Table 5. Delta values from baseline to week 24 of follow-up according to virological response.

\begin{tabular}{lccc}
\hline & $\begin{array}{c}\text { Responders }(\mathrm{n}=93) \\
\text { Mean } \pm \text { SD }\end{array}$ & $\begin{array}{c}\text { Relapsers }(\mathrm{n}=7) \\
\text { Mean } \pm \text { SD }\end{array}$ & $\begin{array}{c}\text { MW-U } \\
\mathrm{P} \text { value }\end{array}$ \\
\hline Delta HOMA-IR & $-1.1 \pm 1.6$ & $-1.2 \pm 2.2$ & 0.622 \\
Delta LDL (mg/dL) & $+24 \pm 30$ & $+7 \pm 53$ & 0.271 \\
Delta LDL/HDL ratio & $+0.3 \pm 1.1$ & $-0.05 \pm 0.69$ & 0.188 \\
Delta non-HDL cholesterol (mg/dL) & $+16 \pm 30$ & $-6 \pm 51$ & 0.211 \\
Delta ApoA1 (mg/dL) & $-19 \pm 34$ & $-1.1 \pm 0.19$ & 0.065 \\
Delta ApoB / ApoA1 ratio & $+0.06 \pm 0.13$ & $+1.6 \pm 2.5$ & 0.012 \\
Delta Lp(a) (mg/dL) & $+4.3 \pm 7.1$ & 0.206 \\
\hline
\end{tabular}

MW-U: Mann-Whitney U test. SD: Standard deviation. HOMA-IR: Homeostatic Model Assessment of Insulin Resistance. LDL: Low density lipoprotein. HDL: High density lipoprotein. ApoA1: Apolipoprotein A1. ApoB: Apolipoprotein B. Lp(a): Lipoprotein (a). BMI: Body mass index.

Table 6. Predictors of ApoA1 decrease.

\begin{tabular}{lcccc} 
& $\begin{array}{c}\text { Univariate } \\
\text { OR }(95 \% \mathrm{Cl})\end{array}$ & $\mathrm{P}$ & $\begin{array}{c}\text { Multivariate } \\
\text { OR }(95 \% \mathrm{Cl})\end{array}$ \\
\hline Male sex & $3,556(1,379-9,169)$ & 0.009 & $3,434(1,310-9,002)$ & 0.012 \\
\hline SVR & $4,571(0,947-22,059)$ & 0.058 & $4,167(0,804-21,605)$ & 0.089 \\
\hline
\end{tabular}

We reported only factors found to be significant at Univariate analysis ( $p$ value $<0.1)$. OR: Odds ratio. Cl: Confidence interval. SVR: Sustained virological response.

Table 7. Predictors of ApoB/ApoA1 ratio increase.

\begin{tabular}{lcccc}
\hline & $\begin{array}{c}\text { Univariate } \\
\text { OR }(95 \% \mathrm{Cl})\end{array}$ & $\mathrm{P}$ & $\begin{array}{c}\text { Multivariate } \\
\text { OR }(95 \% \mathrm{Cl})\end{array}$ \\
\hline Male sex & $2,277(0,960-5,400)$ & 0.062 & $2,849(0,944-8,602)$ & 0.063 \\
SVR & $6,442(1,175-35,307)$ & 0.032 & $1,953(0,330-11,575)$ & 0.461 \\
\hline
\end{tabular}

We reported only factors found to be significant at Univariate analysis ( $p$ value <0.1). OR: Odds ratio. Cl: Confidence interval. SVR: Sustained virological response. 
Table 8. Predictors of $L p(a)$ rise.

\begin{tabular}{lcccc}
\hline & $\begin{array}{c}\text { Univariate } \\
\text { OR }(95 \% \mathrm{Cl})\end{array}$ & $\mathrm{P}$ & $\begin{array}{c}\text { Multivariate } \\
\text { OR }(95 \% \mathrm{Cl})\end{array}$ \\
\hline Male sex & $2,849(0,944-8,602)$ & 0.063 & $2,457(0,789-7,654)$ & 0.121 \\
Advanced fibrosis & $3,277(1,015-10,581)$ & 0.047 & $2,036(0,549-7,552)$ & 0.288 \\
RBV & $3,920(1,206-13,144)$ & 0.023 & $3,982(1,206-13,144)$ & 0.023 \\
\hline
\end{tabular}

We reported only factors found to be significant at Univariate analysis ( $p$ value <0.1). OR: Odds ratio. Cl: Confidence interval. RBV: Ribavirin.

lipid metabolism but we have not elements to explain it. Further dedicated studies might investigate the possible molecular interaction between RBV and lipid metabolism.

This study has some limitations. The first is the relatively small number of patients included, but the size of this cohort is similar to others reported in previous studies. ${ }^{11,14-16,23}$ Another limitation is the retrospective design. On the other hand, to the best of our knowledge, this is the first study offering the following novelties regarding the effect of DAA on glucose and lipid metabolism:

- The first real-life study analyzing whole-body glucose, lipid and behavioral patterns.

- The first examining LDL/HDL ratio, ApoB/ApoA1 ratio, non-HDL cholesterol and mostly $\operatorname{Lp}(\mathrm{a})$ that is a strong drug-resistant predictor of CV events; and

- The first with a such long observation period.

In conclusion, since $\mathrm{HCV}$ positive patients show a major CV risk with respect to non-infected subjects ${ }^{30,31}$ and IFN-based therapy decreases that risk, ${ }^{13}$ we expected that DAA might also have a positive impact on the CV profile. In this context, we reported that the viral clearance due to DAA led to an improvement of glucose metabolism associated with a global worsening of lipid profile. Further prospective studies with long follow-up period and specific cardiological assessments are mandatory to verify if the modifications of lipid profile might be simply a return to a pre-virological state and to analyze the potential impact of those alterations on the $\mathrm{CV}$ risk. Notably, the negative effect on the lipid profile may be at least partially compensated by the decrease of IR, which itself should reduce the CV risk. ${ }^{32}$ Markedly, our data are not enough to establish any possible impact of DAA on the CV global risk. However, evaluating the whole lipid profile at baseline and after the end of DAA treatment would be informative. Patients who have one or more classical CV risk factors and are treated with DAA might be monitored for an accurate stratification of CV risk.

\section{ABBREVIATIONS}

- ApoA1: apolipoprotein A1.

- ApoB: apolipoprotein B.

- CHC: chronic hepatitis C.

- CI: confidence interval.

- CV: cardiovascular.

- DAA: direct-acting antivirals.

- GT: genotype.

- HCV: hepatitis C virus.

- HDL: high-density lipoprotein.

- HOMA-IR: homeostatic model assessment of insulin resistance.

- IFN: interferon.

- IR: insulin resistance.

- LDL: low-density lipoprotein.

- Lp(a): lipoprotein (a).

- MS: metabolic syndrome.

- OR: Odds Ratio.

- RBV: ribavirin.

- sd: standard deviation.

- SOF: sofosbuvir.

- SVR: sustained virological response.

\section{DISCLOSURE STATEMENT}

This research did not receive any specific grant from funding agencies in the public, commercial, or not-forprofit sectors.

\section{REFERENCES}

1. Ye J. Reliance of host cholesterol metabolic pathways for the life cycle of hepatitis C virus. PLoS Pathog 2007; 3 : e108. DOI: 10.1371/journal.ppat.0030108.

2. Popescu $\mathrm{Cl}$, Dubuisson J. Role of lipid metabolism in hepatitis C virus assembly and entry. Biol Cell 2010; 102: 63-74. DOI: 10.1042/BC20090125.

3. Zhang F, Sodroski C, Cha H, Li Q, Liang TJ. Infection of Hepatocytes with HCV Increases Cell Surface Levels of Heparan Sulfate Proteoglycans, Uptake of Cholesterol and Lipoprotein, and Virus Entry by Upregulating SMAD6 and SMAD7. Gastroenterology 2017; 152: 257-70. DOI: 10.1053/ j.gastro.2016.09.033. 
4. Andre P, Komurian-Pradel F, Deforges S, Perret M, Berland $\mathrm{JL}$, Sodoyer M, Pol S, et al. Characterization of low- and very-low-density hepatitis $C$ virus RNA-containing particles. J Virol 2002; 76: 6919-28. DOI: 10.1128/JVI.76.14.69196928.2002.

5. Tao W, Xu C, Ding Q, Li R, Xiang Y, Chung J, Zhong J. A single point mutation in $\mathrm{E} 2$ enhances hepatitis $C$ virus infectivity and alters lipoprotein association of viral particles. Virology 2009; 395: 67-76.

6. Bugianesi E, Salamone F, Negro F. The interaction of metabolic factors with HCV infection: does it matter? J Hepatol 2012; 56: S56-S65.

7. Moucari R, Asselah T, Cazals-Hatem D, Voitot H, Boyer N, Ripault MP, Sobesky $\mathrm{R}$, et al. Insulin resistance in chronic hepatitis C: association with genotypes 1 and 4, serum HCV RNA level, and liver fibrosis. Gastroenterology 2008; 134 : 416-23.

8. Poynard T, Ratziu V, McHutchison J, Manns M, Goodman Z, Zeuzem S, Younossi Z, et al. Effect of treatment with peginterferon or interferon alfa-2b and ribavirin on steatosis in patients infected with hepatitis C. Hepatology 2003; 38: 75-85.

9. $\quad$ Qing S, Ji D, Li B, Li F, Wang Y, Niu X, Ling B, et al. Improvement of glucose and lipid metabolism with pegylated interferon-a plus ribavirin therapy in Chinese patients chronically infected with genotype $1 \mathrm{~b}$ hepatitis C virus. Ann Saudi Med 2015; 35: 293-7.

10. Lange CM, Von Wagner M, Bojunga J, Berg T, Farnik H, Hassler A, Sarrazin C, et al. Serum lipids in European chronic HCV genotype 1 patients during and after treatment with pegylated interferon-alfa-2a and ribavirin. Eur J Gastroenterol Hepatol 2010; 22: 1303-7.

11. Mauss S, Berger F, Wehmeyer MH, Ingiliz P, Hueppe D, Lutz $T$, Simon KG, et al. Effect of antiviral therapy for HCV on lipid levels. Antivir Ther 2016.

12. Corey KE, Kane E, Munroe C, Barlow LL, Zheng H, Chung RT. Hepatitis $C$ virus infection and its clearance alter circulating lipids: implications for long-term follow-up. Hepatology 2009; 50: 1030-7. DOI: 10.1002/hep.23219.

13. Hsu YC, Ho HJ, Huang YT, Wang HH, Wu MS, Lin JT, Wu CY. Association between antiviral treatment and extrahepatic outcomes in patients with hepatitis C virus infection. Gut 2015; 64: 495-503.

14. Meissner EG, Lee YJ, Osinusi A, Sims Z, Qin J, Sturdevant $\mathrm{D}$, McHutchison $\mathrm{J}$, et al. Effect of sofosbuvir and ribavirin treatment on peripheral and hepatic lipid metabolism in chronic hepatitis C virus, genotype 1-infected patients. Hepatology 2015; 61: 790-801.

15. Younossi ZM, Stepanova M, Estep M, Negro F, Clark PJ, Hunt $S$, Song $Q$, et al. Dysregulation of distal cholesterol biosynthesis in association with relapse and advanced disease in CHC genotype 2 and 3 treated with sofosbuvir and ribavirin. J Hepatol 2016; 64: 29-36.

16. Hashimoto S, Yatsuhashi H, Abiru S, Yamasaki K, Komori A, Nagaoka S, Saeki A, et al. Rapid Increase in Serum LowDensity Lipoprotein Cholesterol Concentration during Hepatitis C Interferon-Free Treatment. PLoS One 2016; 11: e0163644. DOI: 10.1371/journal.pone.0163644.

17. Schmidt C, Bergstrom G. Apolipoprotein B and apolipopotein A-I in vascular risk prediction - a review. Curr Pharm Des 2014; 20: 6289-98.

18. McQueen MJ, Hawken S, Wang X, Ounpuu S, Sniderman A, Probstfield J, Steyn K, et al. Lipids, lipoproteins, and apolipoproteins as risk markers of myocardial infarction in 52 countries (the INTERHEART study): a case-control study. Lancet 2008; 372: 224-33.
19. Dallmeier D, Koenig W. Strategies for vascular disease prevention: the role of lipids and related markers including apolipoproteins, low-density lipoproteins (LDL)-particle size, high sensitivity C-reactive protein (hs-CRP), lipoprotein-associated phospholipase A2 (Lp-PLA $)_{2}$ ) and lipoprotein(a) (Lp(a)). Best Pract Res Clin Endocrinol Metab 2014; 28: 281-94.

20. Arciello A, Piccoli R, Monti DM. Apolipoprotein A-I: the dual face of a protein. FEBS Lett 2016.

21. Nordestgaard BG, Langsted A. Lipoprotein (a) as a cause of cardiovascular disease: insights from epidemiology, genetics, and biology. J Lipid Res 2016; 57: 1953-75.

22. Nordestgaard BG, Chapman MJ, Ray K, Boren J, Andreotti F, Watts GF, Ginsberg H, et al. Lipoprotein(a) as a cardiovascular risk factor: current status. Eur Heart J 2010; 31: 284453.

23. Younossi ZM, Elsheikh E, Stepanova M, Gerber L, Nader F, Stamm LM, Brainard DM, et al. Ledipasvir/sofosbuvir treatment of hepatitis $C$ virus is associated with reduction in serum apolipoprotein levels. J Viral Hepat 2015; 22: 977-82.

24. Available from: http://www.agenziafarmaco.gov.it/. (Last assessed on 30 th November, 2015).

25. Grundy SM, Cleeman JI, Daniels SR, Donato KA, Eckel RH, Franklin BA, Gordon DJ, et al. Diagnosis and management of the metabolic syndrome: an American Heart Association/National Heart, Lung, and Blood Institute Scientific Statement. Circulation 2005; 112: 2735-52.

26. Bassendine MF, Sheridan DA, Bridge SH, Felmlee DJ, Neely RD. Lipids and HCV. Semin Immunopathol 2013; 35: 87-100.

27. Vezali E, Aghemo A, Colombo M. A review of the treatment of chronic hepatitis $C$ virus infection in cirrhosis. Clin Ther 2010; 32: 2117-38.

28. Van der Meer AJ, Berenguer M. Reversion of disease manifestations after HCV eradication. J Hepatol 2016; 65: S95S108.

29. Helfand M, Carson S. Screening for lipid disorders in adults: Selective update of 2001 U.S. Preventive Services Task Force review. Prepared for the Agency for Healthcare Research and Quality; by the Oregon Evidence-based Practice Center at the Oregon Health and Science University, Portland, Oregon, under Contract Number 290-02-0024. April 2008. Evidence Synthesis No. 49. AHRQ Publication No. 0805114-EF-1.

30. Adinolfi LE, Zampino R, Restivo L, Lonardo A, Guerrera B, Marrone A, Nascimbeni F, et al. Chronic hepatitis $C$ virus infection and atherosclerosis: clinical impact and mechanisms. World J Gastroenterol 2014; 20: 3410-7. DOI: 10.3748/ wjg.v20.i13.3410.

31. Petta $S$, Maida $M$, Macaluso FS, Barbara $M$, Licata $A$, Craxì A, Cammà C. Hepatitis C Virus Infection Is Associated With Increased Cardiovascular Mortality: A Meta-Analysis of Observational Studies. Gastroenterology 2016; 150: 14555.

32. Reaven GM. Insulin resistance: the link between obesity and cardiovascular disease. Med Clin North Am 2011; 95: 87592.

Correspondence and reprint request: Pietro Andreone, M.D., Professor.

Department of Medical and Surgical Sciences, University of Bologna, Italy.

Via Massarenti 9, 40138 Bologna, Italy.

Tel.: +39-051-2143618. Fax: +39-051-345806 E-mail: pietro.andreone@unibo.it 